\title{
Visceral neoplasia and epidermal papillomas in cultured turbot Scophthalmus maximus
}

\author{
Jesus Lamas ${ }^{1}$, Ramon Anadon $^{1}$, Sergio Devesa ${ }^{2}$, Alicia E. Toranzo ${ }^{3}$ \\ ${ }^{1}$ Departamento de Biologia Fundamental, Facultad de Biologia, Universidad de Santiago de Compostela, \\ E-15706 Santiago de Compostela, Spain \\ ${ }^{2}$ Neptuno Acuicultura S. A., Riveira, E-15960, La Coruña, Spain \\ ${ }^{3}$ Departamento de Microbiología y Parasitologia, Facultad de Biologia, Universidad de Santiago de Compostela, \\ E-15706 Santiago de Compostela, Spain
}

\begin{abstract}
Skin papillomas, mainly composed of epidermal hyperplasia and visceral tumors involving the pancreatic and occasionally the bile ducts, were observed in a population of juvenile turbot Scophthalmus maximus reared in a fishfarm located in the northwest of Spain. By electron microscopy, the epidermal hyperplastic tissue had Malpighian cells with irregular nuclei and abundant glycogenlike particles and free ribosomes in the cytoplasm. In visceral tumors, proliferation of the pancreatic ductular epithelial cells was accompanied by growth of surrounding smooth muscle cells and connective tissue. Pancreatic acinar cells were vacuolated. Some affected fish also presented lesions in the liver, spleen and kidney. Attempts to isolate virus using different fish cell-lines were negative. Similarly, no viral particles were observed by electron microscopy. However, bacteriological analysis revealed the presence of the Vibrio fischeri - V. harveyi group in the internal organs of the majority of affected fish, which supports a possible contribution of these bacteria in the development of mortality. High pressure liquid chromatography analysis has not detected the presence of aflatoxin $B_{1}$ in tissues. At present the origin of these tumors in turbot remains unclear
\end{abstract}

\section{INTRODUCTION}

In October-November 1988, a new pathological syndrome was observed in one stock (17000 fish) of imported turbot Scophthalmus maximus (mean weight $60 \mathrm{~g}$ ) reared at a fishfarm in Galicia (northwest Spain). All fish were maintained in concrete tanks with an open water-flow and were fed with a semimoist pellet prepared in the rearing plant.

The majority $(70 \%)$ of affected turbot showed numerous whitish nodules in the dorsal skin, some of which presented an apical haemorrhagic ulceration, and internally a large and compact visceral mass, involving the pancreas and occasionally the bile ducts. A moribund turbot exhibited only $20 \%$ external or $10 \%$ internal lesions.

This syndrome was noticed 3 mo after the fish importation, causing a low but continuous mortality which did not arrest with chemotherapy. Interestingly, the pathological problem still remains in the culture facility. Total cumulative losses over a 1 yr period were $39 \%$ of the affected population.
Epidermal papillomas have been described in flatfish of the Pacific coast of the United States (Wellings 1969), in the German Bight (Peters \& Watermann 1979) and in the coastal waters of Hokkaido (Japan) (Katsura et al. 1984). These skin tumors were also a common condition in cultured fish and were frequently associated with a virus (Kelly at al. 1983, Yamamoto et al. 1985), water pollution (Smith et al. 1989a, b), as well as a result of mechanical stimulation (Peters \& Watermann 1979).

Tumors of the pancreatic and bile ducts are rare. Multiplication of the bile ducts has been found in winter flounder Pseudopleuronectes americanus from Boston Harbor, although its origin was unknown (Murchelano \& Wolke 1985). Proliferation of the bile ducts has also been reported in rainbow trout (Oncorhynchus mykiss, formerly Salmo gairdneri) affected by aflatoxicosis (Ashley 1965).

This paper reports the first description of tumors in the skin and/or pancreatic and bile ducts of cultured turbot. Studies of other internal lesions associated with the presence of these tumors, as well as a microbiological analysis of diseased turbot, were also conducted. 


\section{MATERIALS AND METHODS}

A total of 30 juvenile turbot Scophthalmus maximus presenting simultaneously both skin and internal nodules were sampled during 1 a 2 mo period to determine the possible causes of the mortality. For comparative purposes, samples from apparently healthy fish were also analyzed. Fish were subjected to bacteriological and virological analyses, as well as to histopathological studies using light and electron microscopy. Determination of aflatoxin $B_{1}$ in fish tissues was also carried out.

Histopathological studies. Light microscopy: Samples of gills, liver, spleen, kidney, heart and gut and portions of visceral and skin tumors masses were removed of diseased fish and fixed with $5 \%$ formalin in $0.1 \mathrm{M}$ phosphate buffer or with Bouin's fluid. Tissue pieces were processed for routine paraffin wax embbeding. Sections $7 \mu \mathrm{m}$ thick were stained with haematoxylin and eosin (H \& E), periodic acid Schiff (PAS) or with haemalum-picro-indigo carmine (HPI).

Electron microscopy: Small blocks of the tumor masses were fixed with cold $1 \%$ glutaraldehyde and $1.5 \%$ formaldehyde in $0.1 \mathrm{M}$ sodium cacodylate buffer $(\mathrm{pH} 7.2)$, left for $6 \mathrm{~h}$, rinsed in buffer and postfixed for $2 \mathrm{~h}$ with cold $1 \% \mathrm{OsO}_{4}$ in the same buffer. Following dehydration in graded ethanol and propylene oxide they were embbeded in Epon 812. Control semithin sections were stained with toluidine blue-borax and ultrathin sections were stained with lead citrate.

Microbiological studies. Bacteriological analysis: For bacterial isolation, samples taken from the spleen, liver, kidney, gills and damaged skin of moribund turbot were streaked on tryptic soy agar (TSA) (Difco) with $2 \% \mathrm{NaCl}$ added, marine agar (Z-2216) (Difco), and thiosulphate citrate bile sucrose (TCBS) agar (Oxoid).

Smears from the different organs as well as from the normal and damaged skin were examined using phase contrast microscopy or Gram stain.

Before taking samples from the skin and gills, fish were flushed with sterile seawater to remove the accidental non-attached marine microflora.

Pure cultures of the isolated colonies were subjected to taxonomic analysis using standard morphological, physiological and biochemical plate and tube tests following basically the procedures of West \& Colwell (1984) and Fouz et al. (1990). Final identification of bacterial strains was conducted according to the schemes of Amos (1985) and Austin \& Austin (1987).

The drug susceptibility of isolates was assayed by the disc diffusion method on Mueller-Hinton agar with $\mathrm{NaCl}$ added using the following drugs ( $\mu \mathrm{g} \operatorname{disc}^{-1}$ ): ampicillin (10), chloramphenicol (30), streptomycin (15), oxytetracycline (30), eryrthromycin (15), nitro- furantoin (300), oxolinic acid (2), Trimethoprimsulphamethoxazole (25) and the vibriostatic agent $0 / 129(150)$

Virus isolation attempts: Spleen, liver and kidney tissues, as well as the external and internal tumors were removed from fish and processed following standard virological procedures (Amos 1985).

The chinook salmon embryo (CHSE-214), fathead minnow peduncle (FHM) and epithelioma papillosum cyprini (EPC) cell lines were utilized for virological analysis. All cell types were routinely cultivated with Eagle's minimum essential medium with Earle's salts (EMEM) supplemented with $10 \%$ newborn calf serum (NBS) and containing 100 units penicillin, $100 \mu \mathrm{g}$ streptomycin and $50 \mu \mathrm{g}$ gentamicin per $\mathrm{ml}$. The CHSE cell line was incubated at $15^{\circ} \mathrm{C}$ whereas FHM and EPC cells were at $25^{\circ} \mathrm{C}$.

Determination of aflatoxin $B_{1}$ in fish tissues. Visceral organs from 5 fish each weighing about $50 \mathrm{~g}$, were ground and shaken (for $1 \mathrm{~h}$ ) in a flask containing $200 \mathrm{ml}$ of acetonitrile and $30 \mathrm{ml}$ of distilled water. The extraction, clean up and derivatization was carried out according to the method of Cohen \& Lapointe (1981). Aflatoxin $B_{1}$ (Sigma) was used as control.

The samples and the control were analyzed by high pressure liquid chromatography (HPLC) using a radial compression module with a $10 \mathrm{~cm} \times 8 \mathrm{~mm}$ Radial-Pack $10 \mu \mathrm{m} \mathrm{C}_{18}$ column at a flow rate of $1 \mathrm{ml} \mathrm{min}^{-1}$. Aflatoxin was detected by fluorescence with a detector operated at an excitation wavelenght of $365 \mathrm{~nm}$, and with an emission filter of $418 \mathrm{~nm}$. Aflatoxin $B_{1}$ in a concentration of $2 \mathrm{ng} \mathrm{ml}^{-1}$ was easily detected by this method.

\section{RESULTS AND DISCUSSION}

\section{External and internal clinical signs of diseased fish}

Tumorous turbot usually had both epidermal, whitish lesions and a compact visceral mass at the level of stomach, although in some fish only one type of lesion was found. The epidermal lesions (papillomas) observed only on the dorsal skin of fish were variable in size, discrete, non-pedunculated, randomly distributed and sporadically presented a reddish centre (Figs. 1 and 2). The internal lesion was a white and spherical nodule, up to $1 \mathrm{~cm}$ in diameter, which involved the pancreatic and occasionally the bile ducts (Fig. 3)

Some fish also presented other pathological signs such as a pale liver with petechia, the intestine filled with a mucous fluid and an accumulation of haemorrhagic liquid in the peritoneal cavity (Fig. 3). 

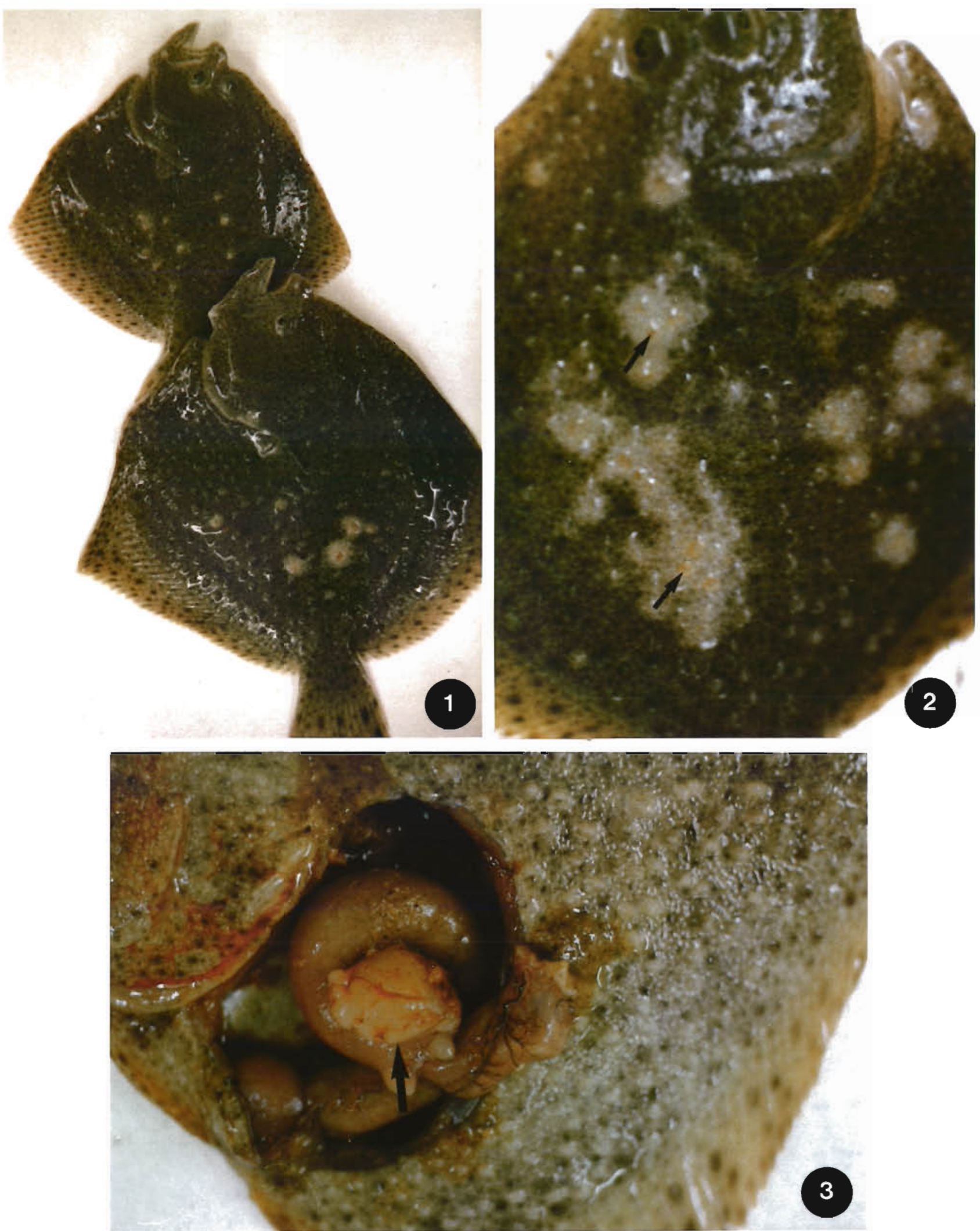

Figs. 1 to 3. Scophthalmus maximus. External signs of visceral neoplasia and epidermal papillomas. Fig. 1. Turbots with discrete skin hyperplasias on dorsal surface. Fig. 2. Closer view of tumors showing a reddish centre (arrows). Fig. 3. Visceral nodule in a tumorous fish (arrow). The abdominal cavity contains abundant haemorrhagic fluid 


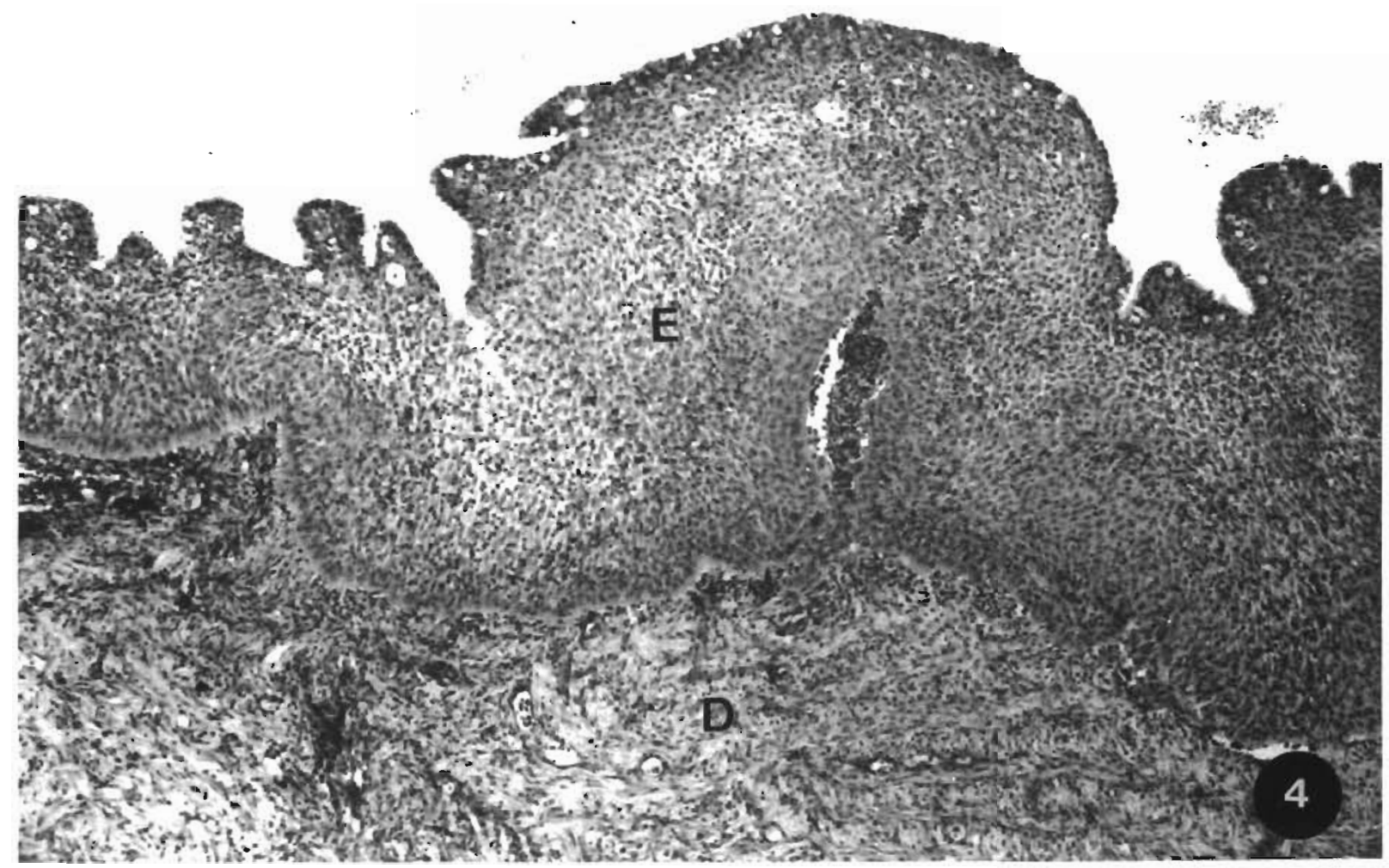

Fig. 4. Scophthalmus maximus. Light micrograph of a section through the skin papilloma. Note the absence of melanocytes and the presence of numerous inflammatory cells in the epidermis ( $E$ ) and in the underlying dermis (D). $H \& E_{j} \times 165$

\section{Histopathological analysis of skin lesions}

While in normal turbot the epidermis contains 4 to 8 layers of Malpighian cells, the hyperplastic epidermis consisted of up 50 layers. The cells of the 4 to 6 basal layers of altered epidermis were columnar in shape and arranged vertically, the cells of the central layers were cuboidal and randomly orientated, and the cells of the 4 to 5 superficial layers were flattened and disposed horizontally. Mucous and club cells were practically absent in papillomas, or smaller in size than in the normal epidermis. Infiltrating cells, specially lymphocytes, were numerous in the affected epidermis, being concentrated in basal and suprabasal areas. Usually the basal membrane was folded and showed a large central and 2 small lateral folds. Melanocytes, absent in the central region of the papilloma, were displaced to the lateral areas. A marked inflammation was noted in the adjacent dermis (Fig. 4). While in transitional regions these inflammatory cells occupied only the stratum spongiosum, in the central region of the papilloma they also invaded the stratum compactum. When the lesion was coincident with a scale, the epidermal hyperplasia was located on the lateral sides, while in the upper side of the scale the epidermis was either absent or very thin. Haemorrhagic zones containing numerous bacteria were observed between the scale and the hyperplastic epidermis.

As the skin lesion showed thickening of the epidermis together with folding of the basal membrane we have termed the lesion epidermal papilloma. The absence of a complete papillar morphology might indicate an initial stage in their development. Although there are differences in location and morphology, the histopathology of the epidermal papillomas observed in turbot resembled skin papillomas of dab (Peters \& Waterman 1979), brown bullhead and white sucker (Smith et al. 1989a, b). As suggested by Smith et al. (1989b), the presence of inflammatory cells in the epidermis might indicate an immune response to some antigenic agents. The inflammation of the dermis might also be a response to the factors liberated by the hyperplastic epidermis

By electron microscopy, Malpighian cells of the intermediate epidermal layers were seen separated by large intercellular spaces and were only linked by their desmosomes (Fig. 5). Nuclei had a markedly irregular surface, with frequent nuclear pseudoinclusions. In 

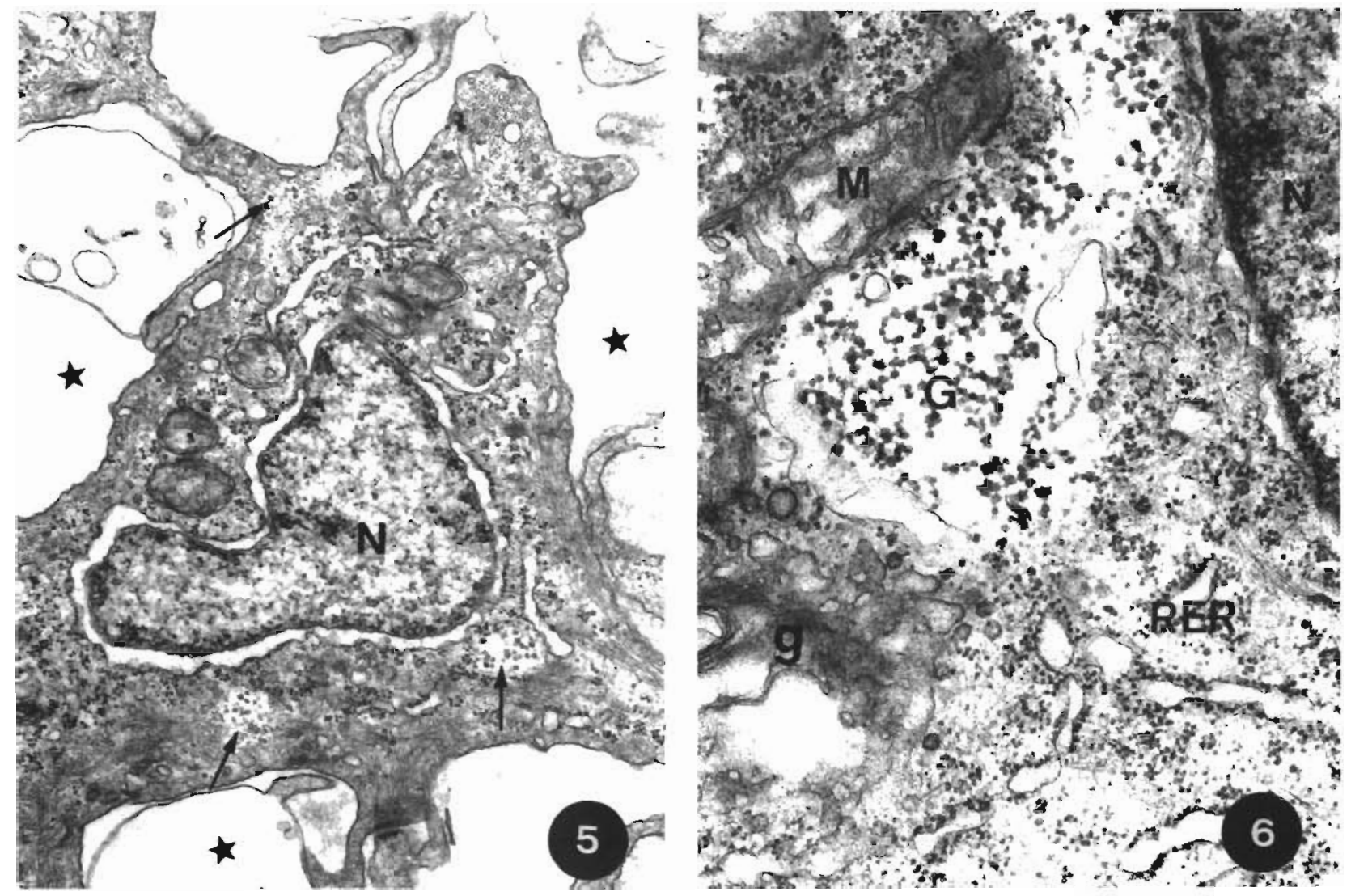

Figs. 5 and 6. Scophthalmus maximus. Transmission electron micrographs of the epidermal hyperplasia. Fig. 5. Malpighian cell of intermediate layers with small amounts of glycogen-like partıcles (arrows) Dilatation of intercellular spaces (star) is characterıstıc of these tumors. N: nucleus. $\times 13800 \mathrm{Flg} 6 \mathrm{High}$ magnification of Malpighian cell containing particulate glycogen (G) among cytoplasmic organelles. RER: rough endoplasmic retıculum, M: mitochondnon. N. nucleus, g. Golgı apparatus. $\times 35000$

addition, Malphigian cells, specially those of basal layers, presented large accumulations of intracytoplasmic glycogen-like particles. Abundant, tree rubosomes were also observed in the cytoplasm (Figs. 5 and 6).

Irregular cell nuclei and increased intercellular spaces between Malpighian cells are frequent in skin papillomas of fish (Emerson et al. 1985, Yamamoto et al. 1985, Smith et al. 1989a). Although epidermal hyperplasia was frequently attributed to a virus (Kelly et al. 1983, Peters et al. 1983, Emerson et al. 1985, Yamamoto et al. 1985), we have not found any viral particles in Malpighian cells by electron microscopy Virions of small size were reported by Emerson et al. (1985) in flounder. Turbot Malpighian cells possesed abundant $30 \mathrm{~nm}$ particles, located exclusively in the cytosol, but here they were identified as glycogen. Furthermore, the presence of large accumulations of glycogen and abundant free ribosomes in the cytoplasm are typical of tumorous cells (Ghadially 1988). Epidermal tumors are also associated with X-cells in flatfish (Brooks et al. 1969, Peters \& Watermann 1979, Peters et al. 1983) but these X-cells were not detected in the epidermis of the turbot studied.

\section{Histopathological study of internal tumors}

The internal tumor mannly consisted of neoplastic pancreatic ducts invading the region of the pancreatic acinı. The proliferation of ducts was accompanied by hyperplasıa of the stroma. composed of smooth muscle cells and connective tissue (Figs. 7 and 8). Ductular cells were cuboidal in shape. Occasionally, the tumor mass infiltrated the stomach

By electron microscopy, these tumorous cells exhibited numerous invaginations of the nuclear envelope, a promment and marginated nucleolus and a large number of free ribosomes. Abundant glycogen partıcles were also observed (Fig. 9).

Pancreatic acinar cells were vacuolated and zymogen granules were numerous (Fig. 10). Often, the acm were surrounded by connective tissue containing numerous inflammatory cells and accumules of lipopigments.

It has been reported (Fourne et al. 1987, 1988) that tısh, either spontaneously or after exposure to carcinogens, can develop exocnne pancreatic tumors. However, neoplasms of the pancreatic ducts are infrequent. 



Figs. 7 and 8 . Scophthalmus maximus. Light micrographs of the visceral tumor Fig. 7 . A large tumoral mass with proliferated pancreatic ducts and stromal tissue has displaced the pancreatic acini to the periphery. P: exocrine pancreas. H \& $E_{i} \times 37$. Fig. 8 . Detail of the neoplastic pancreatic ducts. D: ducts; S: stroma. $H \& E_{i} \times 150$

In fact, the methylazoxymethanol acetate-induced adenocarcinoma in the guppy Poecilia reticulata consists of duct-like elements apparently derived from acinar cells (Fournie et al. 1987). Interestingly, the origin of the tumor described in turbot was ductular proliferation, and no evidence of involvement of acinar cells in this neoplasia was found. Analogous to skin papillomas, no viral particles were observed in the visceral tumor by electron microscopy. Although the influence of these internal lesions on the pancreatic function of turbot is unknown, a pancreatic insufficiency could cause poor assimilation of food and consequently a weakening or, even, the death of the fish.

\section{Other internal lesions in the tumorous iish}

In the majority of turbot, hepatocytes were extensively necrotized and atrophied, and exhibited fat infiltration. In some fish there was proliferation of the bile ducts, with thickening of the external connective layer (Fig. 11) and the nucleus of fatty hepatocytes was located peripherally (Fig. 13).
Lesions were also frequently observed in the spleen. Large amounts of macrophages filled with ceroid and surrounded by numerous lymphocytes were accumulated between the haematopoietic tissue (Fig. 12). The sheath tissues became thick and consequently invaded most of the spleen. The spleen pulp was atrophic and the blood vessels were compressed.

The changes observed in the kidney consisted of the presence of numerous groups of ceroid-laden macrophages within an atrophic haematopoietic tissue. Some of the epithelial renal cells underwent hyalin droplet degeneration. Glomerular sclerosis was also observed.

The majority of lesions found in these organs were unspecific and, therefore, could be related to any infectious or nutritional disease. The presence of high levels of ceroid-laden macrophages in the spleen and kidney as well as the hepatic fatty infiltration might indicate alterations of the fish metabolism. Numerous authors have related fatty accumulation with an increase of carcinogenesis. In rats, unsaturated fats increase the incidence of carcinomas induced by aflatoxin $B_{1}$ (Newberne et al. 1979). Cormier et al. (1989) suggested that the presence of high hepatic lipid levels in Atlantic 


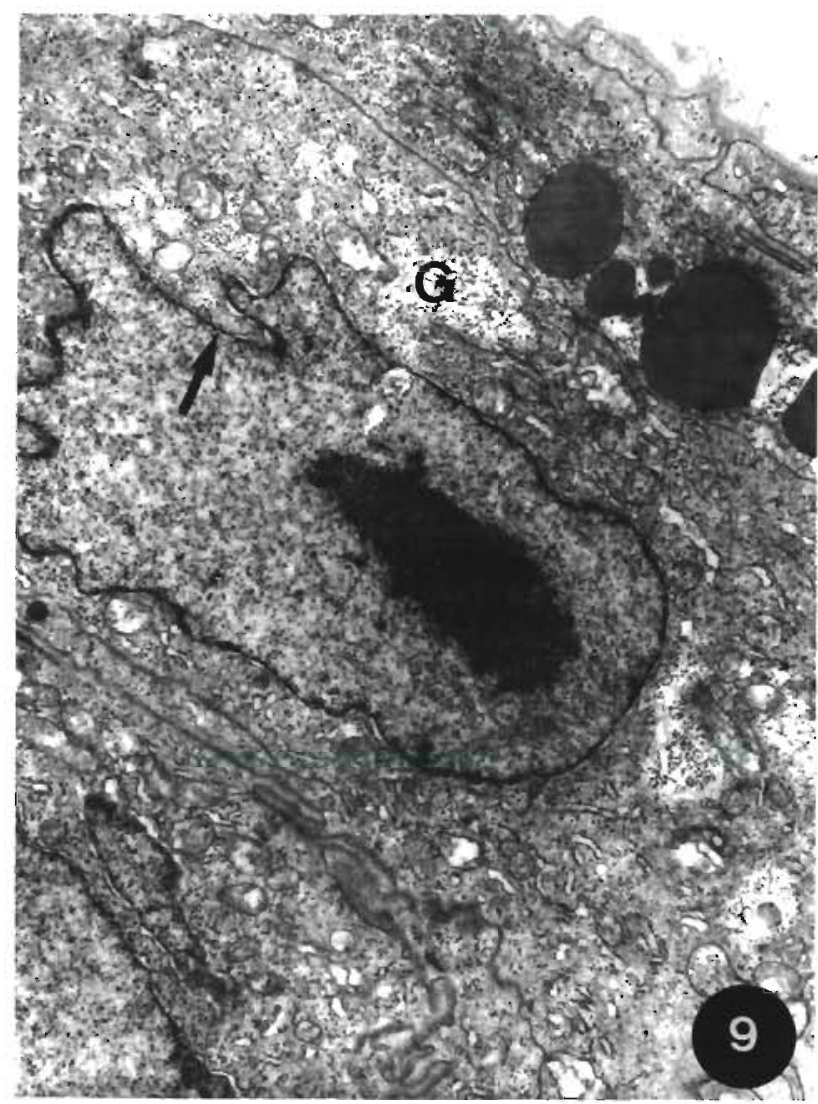

Fig. 9. Scophthalmus maximus. Electron micrograph of a ductular epithelial cell showing invaginations of the nuclear envelope (arrow) and glycogen areas in the cytoplasm (G). $\times 7500$

tomcod may be a metabolic response to detoxification. Under the conditions described in the present study, no aflatoxin $B_{1}$ was found in the visceral organs of affected turbot using HPLC. However, the absence of aflatoxin $B_{1}$ in fish tissues does not preclude the presence of this substance in the food of the fish in the early stages of their growth. Therefore, the relation between fatty accumulation and the origin of these tumors is unknown.

\section{Microbiological examination}

Attempts to isolate the virus using different fish celllines were negative either on primary isolation or in the blind passage. Similarly, no parasitic internal or external infestation was observed.

Bacteriological analysis revealed that whereas bacteria were practically absent from intact skin, the external whitish nodules were colonized by marine bacteria belonging mainly to the Vibrio splendidus $-V$. pelagius group, and to a lesser extent by $V$. fischeri, $V$. harveyi, Acinetobacter, Flavobacterium and myxobac-

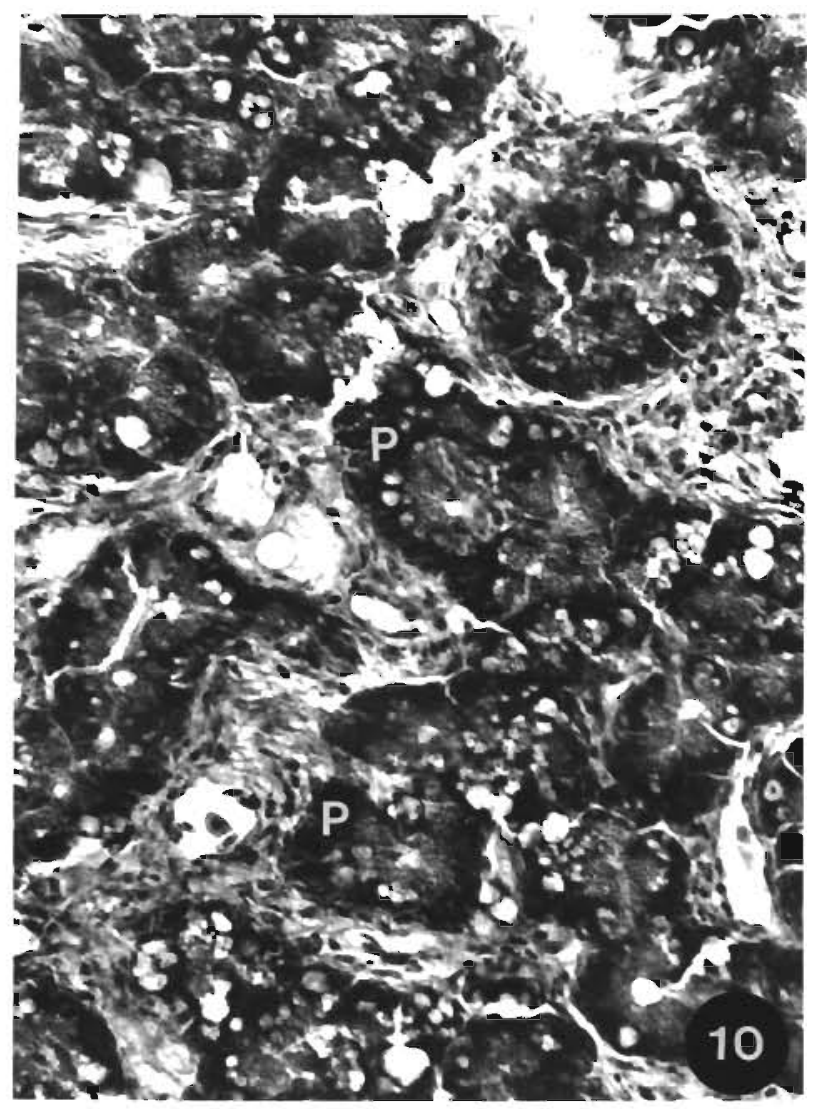

Fig. 10. Scophthalmus maximus. Light micrograph showing pancreatic acini with vacuolated cells $(P)$. Note also the hypertrophied connective tissue. $H \& E_{;} \times 470$

teria. However, only the $V$ fischeri $-V$. harveyi group was present in the liver and kidney of the majority of diseased turbot, almost as a pure culture. Although these strains proved to be sensitive to the drugs tested, the disease did not respond to any chemotherapeutic treatment, indicating that these vibrios do not play the primary role in the syndrome. However, we can not rule out their contribution in the development of fish mortality. In fact, it is noteworthy that over the last few years, bacteria closely related to the $V$. fischeri $-V$. harveyi group have been isolated, always as secondary invasors, from different pathological conditions occurred in turbot, Pacific salmon Oncorhynchus kisutch and Atlantic salmon Salmo salar (Devesa et al. 1989. Toranzo et al. 1989) cultured in northwest Spain.

\section{CONCLUSIONS}

The origin of these tumors in turbot is uncertain. Although viral particles were not found in the skin papillomas or in the neoplastic pancreatic ducts, at present a viral ethiology can not be totally excluded. It 

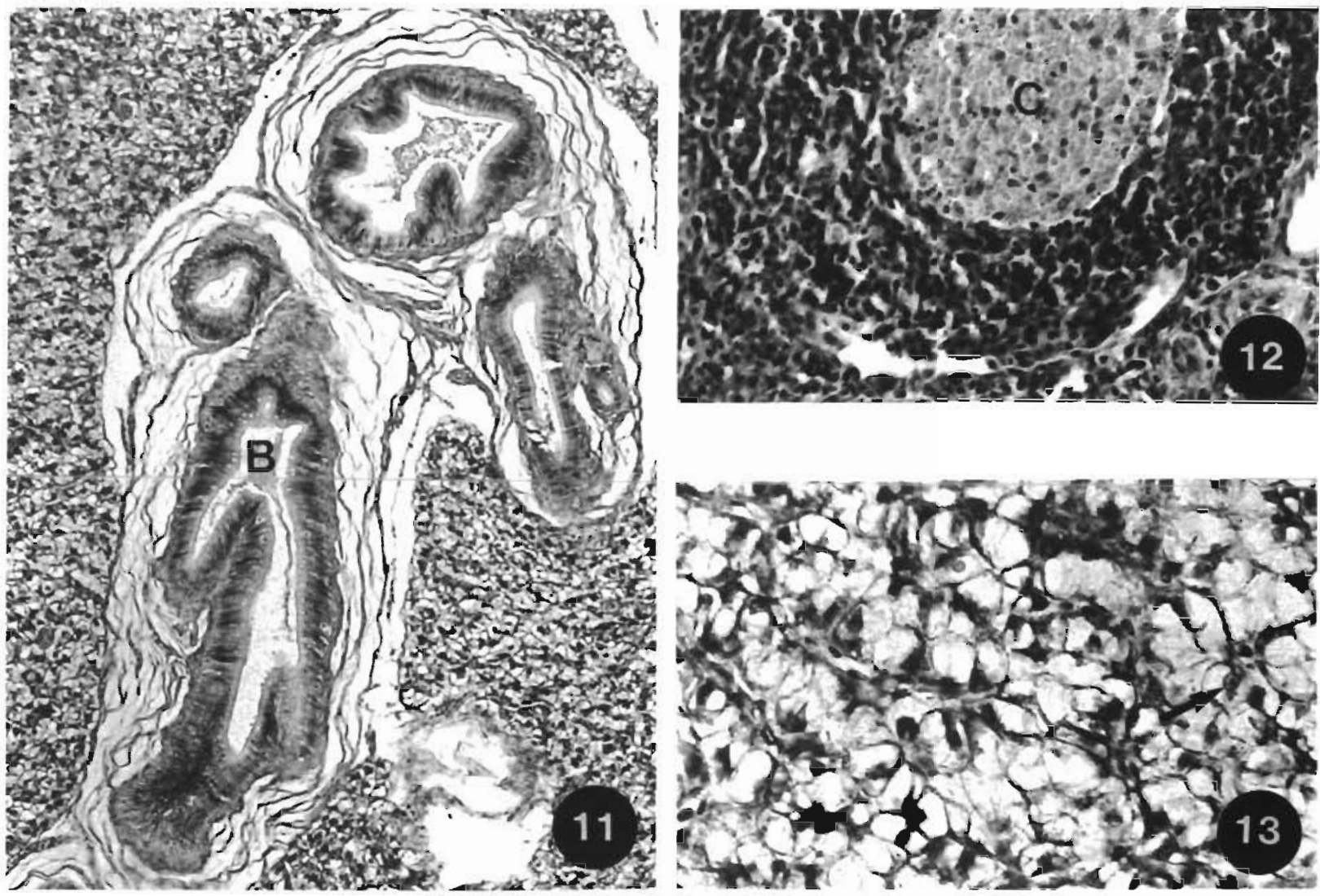

Figs. 11 to 13. Scophthalmus maximus. Fig. 11. Section of liver of tumorous turbot showing proliferation of bile ducts (B). H\& E; $\times 100$. Fig. 12. Spleen of affected turbot. A group of macrophages full of ceroids (C) is encapsulated by numerous lymphocytes. $H \& E_{i} \times 380$. Fig. 13. Closer view of liver showing atrophy of hepatic cells. Note peripheral location of nuclei (arrow). H\& $E_{i} \times 480$

should be noted that healthy and affected fish were fed with the same diet, therefore a nutritional cause is unlikely. However, we can not rule out the possibility that these tumors were a consequence of expossure to some potential carcinogenic agent in the egg, larval or juvenile stages coupled with a genetic predisposition of the affected population of turbot.

The presence of bacteria in the internal organs, together with some of the lesions found in the tumorous turbot seems to indicate that fish mortalities were accelerated by the successful invasion and proliferation of oportunistic Vibrio strains in the immunological impaired fish.

Acknowledgements. This work was supported by Grant AQ018/84 from the Comision Asesora de Investigacion Cientifica y Técnica (CAICYT). Ministerio de Educacion y Ciencia, Spain. J. Lamas thanks the financial support of the Xunta de Galicia.

\section{LITERATURE CITED}

Amos, K. H. (ed.) (1985). Procedures for the detection and identification of certain fish pathogens, 3rd edn. Fish Health Section. Am. Fish. Soc., Corvallis
Ashley, L. M. (1965). Histopathology of rainbow trout aflatoxicosis. Res. Rep. U.S. Fish Wildl. Serv. 70: 103-120

Austin, B., Austin, D. A. (1987). Bacterial fish pathogens: disease in farmed and wild fish. John Wiley \& Sons, New York.

Brooks, R. E., McArn, G. E., Wellings, S. R. (1969). Ultrastructural observations on an unidentified cell type found in epidermal tumors of flounders. J. nati Cancer Inst. 43: 97-109

Cohen, H., Lapointe, M. (1981). High pressure liquid chromatographic determination and fluorescence detection of aflatoxins in corn and dairy feeds. J. Ass. off. analyt. Chem. 64: 1372-1376

Cormier, S. M., Racine, R. N., Smith, C. E., Dey, W. P., Peck, T H. (1989). Hepatocellular carcinoma and fatty infiltration in the Atlantic tomcod, Microgadus tomcod (Walbaum). J Fish Dis. 12: 105-116

Devesa, S., Barja, J. L., Toranzo, A. E. (1989). Ulcerative skin and fin lesions in reared turbot, Scophthalmus maximus (L.). J. Fish Dis. 12: 323-333

Emerson, C. J., Payne, J. F., Bal, A. K. (1985). Evidence for the presence of a viral nonlymphocystis type disease in winter flounder Pseudopleuronectes americanus (Walbaum). from the north-west Atlantic. J. Fish Dis. 8: 91-102

Fournie, J. W.. Black, J. J., Vethaak, A. D. (1988). Exocrine pancreatic adenomas in the greater redhorse. Moxostoma valenciennesi Jordan, and in the European flounder Platichthys flesus (L). J. Fish Dis. 11: 445-448

Fournie, J. W. Hawkins, W. E., Overstreet, R. M., Walker, W. 
W. (1987). Exocrine pancreatic neoplasms induced by methylazoxymethanol acetate in the guppy Poecilia reticulata. JNCI 78: 715-725

Fouz, B., Conchas, R. F., Bolinches, J., Romalde, J. L., Barja, J. L., Toranzo, A. E. (1990). Relationship among pathogenic Vibrio anguillarum and Vibrio tubiashii with environmental vibrios. In: Perkins, F. O., Cheng, T C. (eds.). Pathology in marine science. Academic Press, New York, p. 77-89

Ghadially, F. N. (1988). Ultrastructural pathology of the cell and matrix, 3rd edn. Butterworths, London

Katsura, K., Yamazaki, F., Hamada, K., Oiski, K., Harada, T., Shinkawa, T (1984). Geographic distribution and frequency of tumorous fishes collected from the coastal waters of Hokkaido, Japan. Bull. Jap. Soc. scient Fish. 50: 979-984

Kelly, R. K., Nielsen, O., Mitchell, S. C., Yamamato, T (1983), Characterization of Herpesvirus vitreum isolated from hyperplastic epidermal tissue of walleye, Stizostedion vitreum vitreum (Mitchill) (1983). J. Fish Dis. 6: 249-260

Murchelano, R. A., Wolke, R. E. (1985). Epizootic carcinoma in the winter flounder. Pseudopleuronectes americanus. Science 228: $587-589$

Newberne, P. M., Weigert, J., Kula, N. (1979). Effects of dietary fat on hepatic mixed-function oxidases and hepatocellular carcinoma induced by aflatoxin $B_{1}$ in rats. Cancer Res. 39: 3986-3991

Peters, N., Schmidt, W., Kranz, H., Stich, H. F. (1983). Nuclear inclusions in the X-cells of skin papillomas of Pacific flatfish. J. Fish Dis. 6: 533-536

Responsible Subject Editor: Professor N. Peters, Hamburg, F. R. Germany
Peters, N., Watermann, B. (1979). Three types of skin papillomas of flatfishes and their causes. Mar. Ecol. Prog. Ser 1: 269-276

Smith, I. R., Baker, K. W., Hayes, M. A., Ferguson, H. W. (1989a). Ultrastructure of malpighian and inflammatory cells in epidermal papillomas of white suckers Catostomus commersoni. Dis. aquat. Org. 6: 17-26

Smith, I. R. Ferguson, H. W., Hayes, M. A. (1989b). Histopathology and prevalence of epidermal papillomas epidemic in brown bullhead. Ictalurus nebulosus (Lesueur), and white sucker, Catostomus commersoni (Lacépède), populations from Ontario, Canada. J. Fish Dis. 12: $373-388$

Toranzo, A. E., Ledo, A., Santos, Y., Romalde, J. L., Bandin, I., Fouz, B., Barja, J. L. (1989). Evolution of the bacterial fish diseases in trout, salmon and turbot cultured in Northwest of Spain. European Aquaculture Society Spec. Publ. 10 : $247-248$

Wellings, S. R. (1969). Neoplasia and primitive vertebrate phylogeny. A review. Natl. Cancer. Inst. Monogr 31. 59-128

West, P., Colwell, R. R. (1984), Identification and classification of Vibrionaceae. An overview. In: Colwell, R. R. (ed.) Vibrios in the environment. John Wiley \& Sons, Inc., New York pp. 285-363

Yamamoto, T., Kelly, R. K., Nielsen, O. (1985). Epidermal hyperplasia of walleye, Stizostedion vitreum vitreum (Mitchill), associated with retrovirus like type-C particles: prevalence, histologic and electron microscopic observations. J. Fish Dis. 8: 425-436

Manuscript first received: October 4, 1989

Revised version accepted: April 27, 1990 